\title{
NUMBER OF MACHINE AND MATERIAL REQUIREMENTS FOR PRODUCTION PLANNING OF TABLET TOOLING WITH THE DEMAND OF 200 UNITS/DAY
}

\author{
Nanang Qosim ${ }^{1}$, Andre Kurniawan ${ }^{2 *}$, Moh. Nasir Hariyanto ${ }^{3}$, Zakki F. Emzain ${ }^{4}$, Moh. \\ Hartono $^{5}$, AM Mufarrih ${ }^{6}$
}

Department of Mechanical Engineering, Politeknik Negeri Malang ${ }^{1,3,4,5,6}$

Faculty of Engineering, Universitas Negeri Padang ${ }^{2}$

nanangqsm@polinema.ac.id ${ }^{1}$, andrekurniawan@ ft.unp.ac.id ${ }^{2}$

Received : 24 March 2021, Revised: 04 May 2021, Accepted : 09 May 2021

*Coresponding Author

\begin{abstract}
Shaping and marketing a product in tablet form is an easy and economical alternative to product shaping. Products in tablet form now cover almost all fields, so that the demand for tablet tooling of various sizes and variations continues to increase. As an effort to support the effectiveness and proper industrial planning, it is necessary to carry out an analysis of the machine and material requirements to produce tablet tooling which is the aim of this study. To achieve these objectives, the methods used in this study include product design, operation plan analysis, and calculation of material requirements and number of machines. The result shows that the number of machine requirements to manufacture the die and punch of tablet tooling with the demand of 200 unit/day are two units of power hacksaw, five units of lathe machine, and a unit of milling machine. On the other hand, the material requirements needed in one day are $22.24 \mathrm{~m}$ (Ø45 $\mathrm{mm} \times 5$ bars) and $12.79 \mathrm{~m}$ (Ø18 $\mathrm{mm} \times 3$ bars).
\end{abstract}

Keywords: tablet tooling, number of machines, need of materials, die and punch, demand.

\section{Introduction}

In this era of digitalization, the growth of small and medium economies in Indonesia is growing rapidly. The ease of ordering various kinds of products through various types of digital marketplaces and delivery facilities has stimulated the purchasing power of people that reach all walks of life. This has become a trigger for the increasing number of beginner business actors to produce products that are needed by the community. In the market, products in tablet form are now no longer limited to medicinal products but cover almost all areas. Candies, energy drinks, eco racing (vehicle additives), and many more, are examples of products marketed in tablet form. Even household-scale products also choose tablet form in presenting their products. On this basis, the demand for tablet toolings of various sizes and variations continues to increase.

To support the production process of the tablet tooling, it is necessary to have a factory that is precisely laid out. Because in this industrialization era, the factory is a series of integrated technological systems with extraordinarily complicated layout arrangements and planning. With good facility layout planning, it can provide advantages in the production system, such as increasing production output, reducing delay time, reducing material handling, reducing inprocess inventory, shorter manufacturing processes, and so on. (Deviyanti, Kunhadi, \& Frastian, 2018; Sofyan \& Syarifuddin, 2018; Yang \& Hung, 2007). So that a well-planned factory layout will greatly determine the effectiveness and efficiency of a production process, and in some cases, it will also maintain the continuity and success of a company.

The wide variety of fabrication processes that can be used to form a workpiece gives the possibility of errors in selecting processes and machines. These errors can lead to ongoing financial losses as the process progresses, and it means that these processes and machines are replaced by more efficient alternatives. From a working drawing, a planner with all his knowledge of the forming process will be able to plan alternative forming processes, forming 
process sequences, cutting tools used to form these components/products with a production routing format (Nurchajat, 2017). Due to poor factory layout planning, sophisticated facilities, cutting-edge technology, and good product design will be rendered ineffective. Because an industry's production operations typically last a long time and with a plant layout that does not alter, mistakes in plant layout planning can result in significant losses, even fatalities. (Arif, 2017; Faishol, Hastuti, \& Ulya, 2013; Qosim \& Hartono, 2019). Therefore, it is necessary to plan an effective factory layout so that the production process can take place economically in terms of production costs and is efficient in terms of production time. Based on the things that have been described, it is necessary to conduct a study on the analysis of machine and material requirements for tablet tooling production with the demand of 200 units/day. This careful planning aims so that the production process can take place in accordance with the work plan, namely in accordance with the predetermined operation plan and production routing, as well as efficient use of materials.

\section{Materials and Methods}

\subsection{Production Routing}

The most crucial step in determining the factory layout is determining the production routing. Production Routing contains some information from a die and punch tablet component such as the working stages, the main equipment, and supporting equipment used in the work process. Production routing is a form of work planning that is used to determine the sequence of operational processes carried out in the manufacture of machine components from raw materials to final products. Production routing includes planning and determining the occupation of the department where the work is done using what machines, tools, and auxiliary equipment to use (Adulyasak, Cordeau, \& Jans, 2015). A planner must prepare a list of activities needed to build a machine component by examining the technical drawing first to determine the steps of the work process to be carried out. Production Routing briefly contains Operation Number, Operation Description, Machine, Auxiliary Equipment, Setting Time, Downtime (DT), Allowance, Machining Time, Standard Time (ST) (Apple \& Mardiono, 1990; Hidayat, 2011; Nurchajat, 2017).

\subsection{The calculation of machining time}

Machining time (minute/unit) is directly related to the formation of the workpiece or production time, this time column is filled with the measurement results of machining time per product either by stopwatch time study, work sampling or by using the existing machining time formulations (predetermined time system) against certain standardized work systems (Drozda, 1983). For machining processes that are carried out automatically, the machining time will be the same as normal time, because the machining time for other similar products will require the same time so that there is no need for an adjustment to make the machining time into normal time. For example, here is the equation used to calculate the machining time for a lathe that is used to produce die and punch tablet components.

On the lathe machine, there are two major types of work i.e. facing and longitudinal cutting, which are expressed as follows. (Qosim \& Hartono, 2019):

$$
\begin{aligned}
& \mathrm{Tm}=\frac{\mathrm{df} \times \mathrm{i}}{\mathrm{Sf} \times \mathrm{N}} \\
& \mathrm{Tm}=\frac{1 \times \mathrm{i}}{\mathrm{S} \times \mathrm{N}}
\end{aligned}
$$

Where $\mathrm{df}(\mathrm{mm})$ is the length of surface to be removed; $\mathrm{i}(\mathrm{mm} / \mathrm{rev})$ is the intensity of feeding; $\mathrm{S}$ is the feed rate; $\mathrm{Sf}(\mathrm{mm} / \mathrm{rev})$ is the feed rate for facing process; $\mathrm{N}(\mathrm{rev} / \mathrm{min})$ is the rotation of the engine spindle; and $1(\mathrm{~mm})$ is the length of the surface to be removed plus the tolerance of 1 . The feed rate for the facing process is obtained from the table (Jutz, 2006) whose value depends on the material of both 
workpiece and tool. While the rotation of the engine spindle is obtained from the equation (Dewangga, Nugraha, \& Dantes, 2017):

$\mathrm{N}=\frac{\mathrm{v} \times 1000}{\pi \times \mathrm{d}}$

Where $\mathrm{v}(\mathrm{m} / \mathrm{min})$ is cutting speed; and $\mathrm{d}(\mathrm{mm})$ is the diameter of the workpiece.

Other parameters for deciding lathe machining time can be found in Westermann Tables for The Metal Trade (Jutz, 2006). For other machines used to produce the tablet tooling, such as power hacksaw and milling machines, grinding machines, drilling machines, etc. In general, they have almost the same cutting time or machining time or can be seen in our previous explanation.

\subsection{Standard Time and Output Standard}

The Standard time (ST) and Output Standard (OS) should be calculated using the machining time calculation data. ST is a time estimation standard used by a machine to create one component including the setting time, auxiliary time, and allowance time, as seen in the expression below (Phillips \& Engineers, 1997; Roidelindho, 2017):

$\mathrm{ST}=\mathrm{Tm}+$ Setting time + Allowance time + Auxiliary time

OS is the amount of product that a machine can produce in a single day. A day is believed to have three shifts of work, each lasting eight hours. If the value of ST has been determined, the OS value will be calculated by converting the unit as shown below (Roidelindho, 2017):

OS $=\frac{1}{S T} \times \frac{60 \mathrm{~min}}{1 \text { hour }} \times \frac{24 \text { hours }}{1 \text { day }}$

\subsection{The calculation of the machine requirements}

The calculation of machine requirements is preceded by the calculation of material requirements for each component at each stage of the process, with defects believed to be $0.5 \%$ on the power hacksaw, $1 \%$ on the lathe machine, and $1 \%$ on the milling machine.. The calculations are solved by equation 6 as below (Nurchajat, 2017):

$$
\mathrm{Pn}=\frac{\operatorname{Pg}_{\mathrm{n}}}{1-\operatorname{Pd}_{\mathrm{n}} \%}=\frac{\text { demand }}{1-\operatorname{Pd}_{n} \%}
$$

Where Pn (unit/day) is the material requirement in the n-process; Pgn (unit/day) is a good product in the n-process (unit/day); and Pdn (unit/day) is the defected product in the n-process $(\%)$.

The OS values for each machine and production facility are derived from the calculation of $\mathrm{Tm}$ estimates for each component. Furthermore, the value of material requirements for each process $(\mathrm{P})$ on each machine and production facility is calculated from the calculation of the material need. Equation 7 can be used to estimate the number of production machines $(\mathrm{N})$ required for each component based on this information. (Qosim \& Hartono, 2019).

$\mathrm{N}=\frac{\mathrm{P}}{\mathrm{OS}}$ 


\subsection{The Calculation of Material Requirements} 2017):

Material requirements per day can be obtained from equation 8 as below (Nurchajat,

$\mathrm{M}=\mathrm{P} 1 \times \mathrm{L}$ part $\times \frac{1 \mathrm{~m}}{1000 \mathrm{~mm}} \times \frac{\text { bar }}{\text { length }(\mathrm{m})}$

Where $M$ (bar) is the number of material requirements; L part (mm) is the length of raw material; and P1 (unit/day) is the material requirement in the initial process.

\section{Results and Discussion}

\subsection{Technical drawing of components}

The technical drawing for each component is the most important data in this research. Figure 1 depicts the technical drawing for the tablet tooling's die and punch.
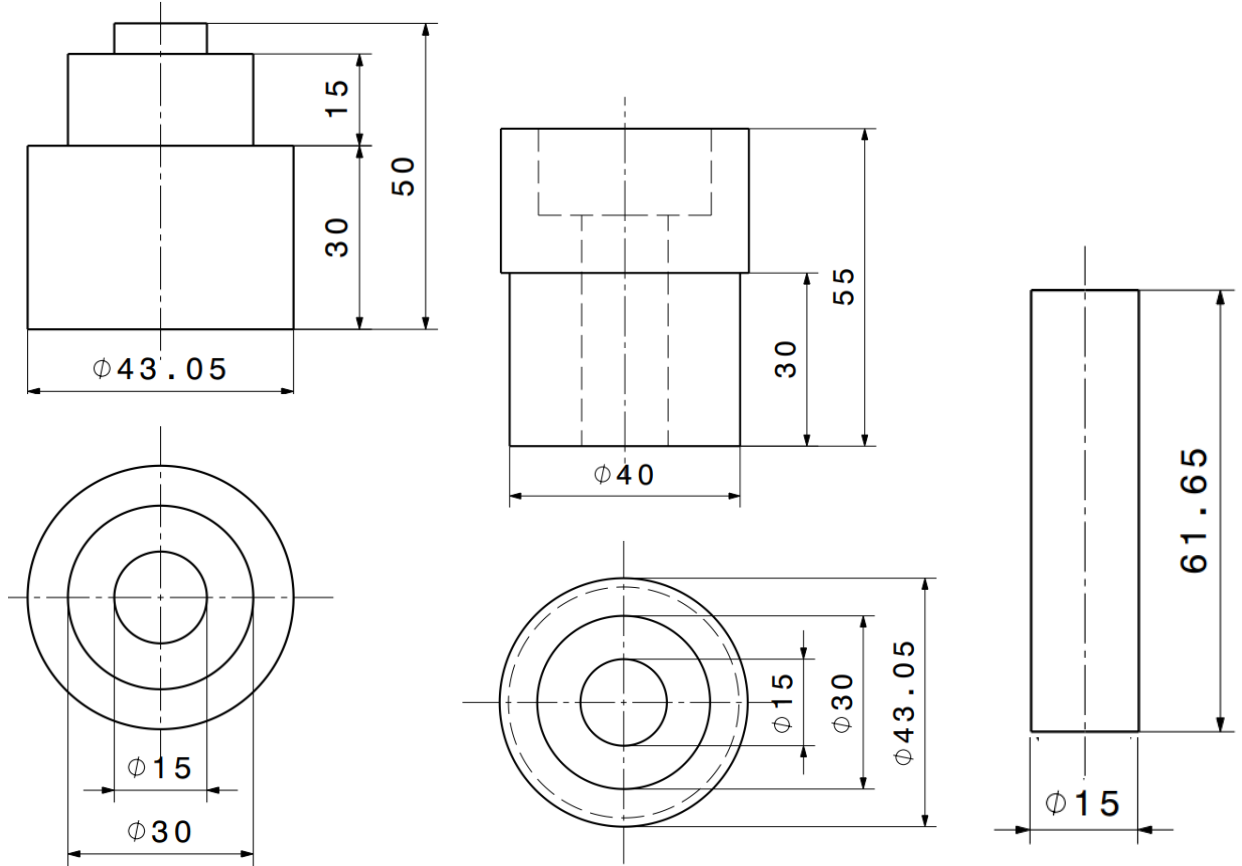

Fig. 1. Main components: (a) Die; (b) Punch; (c) Puncher Shaft

To produce the die dan punch of the tablet tooling, the machines used are power hacksaw, lathes machine, and milling machine. Other processes such as heat treatment and others are assumed to be ordered work.

\subsection{Number of machine requirements}

The calculation data contained in Table 1 is derived from the calculation of machining time for each component.

Table 1 - The Data Of Machining Time Calculation

\begin{tabular}{clcc}
\hline Part & \multicolumn{1}{c}{ Machine } & ST (min/unit) & OS (unit/day) \\
\hline \multirow{2}{*}{ A } & Power hacksaw & 3,00 & 480,00 \\
\cline { 2 - 4 } & Lathe machine & 14,14 & 101,84 \\
\hline \multirow{2}{*}{ B } & Power hacksaw & 3,00 & 480,00 \\
\hline
\end{tabular}




\begin{tabular}{clcc}
\hline & Lathe machine & 12,43 & 115,85 \\
\cline { 2 - 4 } & Milling machine & 3,60 & 400,00 \\
\hline \multirow{2}{*}{$\mathrm{C}$} & Power hacksaw & 1,80 & 800,00 \\
\cline { 2 - 4 } & Lathe machine & 3,27 & 440,37 \\
\hline
\end{tabular}

The next step is to calculate the material requirements for each component at each stage of the process, using the previously described assumptions about defects. The steps of this solution are numbered sequentially in reference to the illustration in Figure 2. Figure 2, as an example, depicts a flow diagram of a material requirement calculation for punch (Part B).

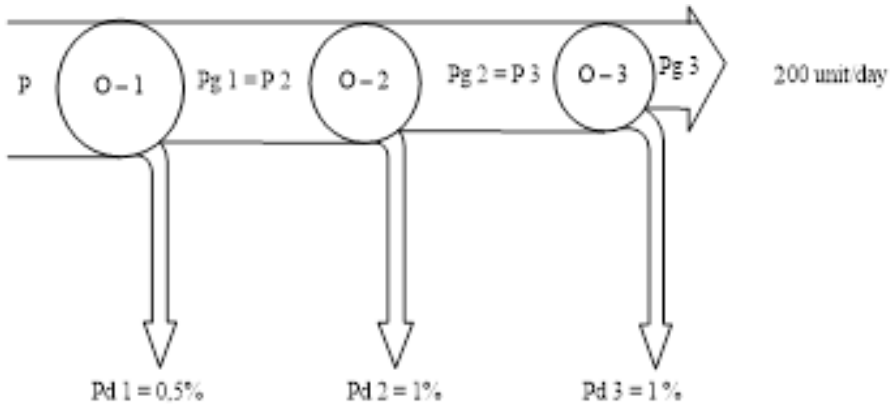

Fig. 2. The material requirement for Part B

As a result, the results of all $\mathrm{N}$ calculations for each component can be found in Table 2 . The total calculation of the need for the machine to produce all components of the tablet tooling with a demand of 200 units/day is given in Table 3.

Table 2 - The Results Of The Calculation For The Number Of Machines Required For Each Component

\begin{tabular}{clcccc}
\hline \multirow{2}{*}{ Part } & Machine & $\begin{array}{c}\text { OS } \\
\text { (unit/day) }\end{array}$ & $\begin{array}{c}\text { Defect of } \\
\text { product } \\
(\% \text { Pd })\end{array}$ & $\begin{array}{c}\text { Product } \\
\text { Prepared (P) } \\
(\text { unit/day })\end{array}$ & $\begin{array}{c}\text { Number of } \\
\text { machines } \\
(\mathrm{N})\end{array}$ \\
\hline \multirow{2}{*}{ A } & Power hacksaw & 480,00 & 0,5 & 203 & 0,42 \\
\cline { 2 - 6 } & Lathe machine & 101,84 & 1 & 202 & 1,98 \\
\hline \multirow{2}{*}{ B } & Power hacksaw & 480,00 & 0,5 & 205 & 0,43 \\
\cline { 2 - 6 } & Lathe machine & 115,85 & 1 & 204 & 1,76 \\
\cline { 2 - 6 } C & Milling machine & 400,00 & 1 & 202 & 0,51 \\
\cline { 2 - 6 } & Power hacksaw & 800,00 & 0,5 & 203 & 0,25 \\
\hline
\end{tabular}

Table 3 - The total need of machine for all components

\begin{tabular}{|c|c|c|c|c|c|}
\hline \multirow[t]{2}{*}{ Machine } & \multicolumn{3}{|c|}{ Part Number } & \multirow{2}{*}{$\begin{array}{c}\text { Total } \\
\text { machine }\end{array}$} & \multirow{2}{*}{ Grand Total } \\
\hline & A & $\mathrm{B}$ & $\mathrm{C}$ & & \\
\hline Power Hacksaw & 0,42 & 0,43 & 0,25 & 1,1 & 2 \\
\hline Lathe machine & 1,98 & 1,76 & 0,46 & 4,2 & 5 \\
\hline Milling machine & - & 0,51 & - & 0,51 & 1 \\
\hline
\end{tabular}


Tables 2 and 3 show that the lathe machine is the most necessary type of machine in the tablet tooling manufacturing process, with a demand of 200 units per day and a total of 5 units. Power hacksaws ( 2 units) and milling machines come in second and third place, respectively (1 unit). These findings suggest that the planned estimates have a high productivity as well as high economic value.

\subsection{Number of material requirements}

Calculation of the total amount of material needed in one production day is carried out with equation 8 . Table 4 below shows the results of these calculations for each component.

Tabel 4 - The total amount of material needed in one production day

\begin{tabular}{|c|c|c|c|c|}
\hline \multirow{2}{*}{$\begin{array}{l}\text { Need of material per day } \\
(\mathrm{mm})\end{array}$} & \multicolumn{3}{|c|}{ Part (m) } & \multirow{2}{*}{ Total (m) } \\
\hline & $\mathrm{A}$ & B & $\mathrm{C}$ & \\
\hline$\varnothing 45$ & 10,56 & 11,68 & - & 22,24 \\
\hline$\varnothing 18$ & - & - & 12,79 & 12,79 \\
\hline
\end{tabular}

From table 4, it can be seen that the total material requirements of $\varnothing 45 \mathrm{~mm}$ and $\varnothing 18$ $\mathrm{mm}$ are $22.24 \mathrm{~m}$ and $12.79 \mathrm{~m}$, respectively. If it is assumed that the material available in the market has a length of 5 meters for a bar, then the daily requirement for $\varnothing 45 \mathrm{~mm}$ and $\varnothing 18 \mathrm{~mm}$ material is 5 bars and 3 bars or 120 bars and 70 bars for the needs in 1 month of production, respectively.

\section{Conclusion}

According to the results of the study, the number of machines required to produce 200 units of tablet tooling is 5 units of lathe machine, 2 units of power hacksaw, and 1 unit of milling machine. In addition, as many as 5 bars of $\varnothing 45 \mathrm{~mm}$ and 3 bars of $\varnothing 18 \mathrm{~mm}$ materials are required per day. It is hoped that these results can make it easier to estimate machine and material requirements for people who want to get into the tablet tooling business. However, the limitation of this study is that it only focuses on simple and cheap machines for low-end industries. Hence, if we want to combine with modern or NC-based machines, further calculation and analysis are needed.

\section{Acknowledgements}

The authors would like to express their thanks to Politeknik Negeri Malang for providing useful support in the form of a research grant No. SP. DIPA-023.18.2.677606/2021 to carry out this study.

\section{References}

Adulyasak, Y., Cordeau, J.-F., \& Jans, R. (2015). The production routing problem: A review of formulations and solution algorithms. Computers \& Operations Research, 55, 141-152.

Apple, J. M. G., \& Mardiono, N. M. T. (1990). Tataletak pabrik dan pemindahan bahan: Penerbit ITB.

Arif, M. (2017). Perancangan Tata Letak Pabrik: Deepublish.

Deviyanti, I. S., Kunhadi, D., \& Frastian, J. (2018). Perencanaan Tata Letak Fasilitas Industri Galangan Kapal Di Lamongan. Matrik (Manajemen dan Teknik Industri-Produksi), 15(1), 67-85.

Dewangga, S. P. F., Nugraha, I. N. P., \& Dantes, K. R. (2017). Pengaruh Variasi Kecepatan Putaran Mesin Bubut Terhadap Keausan Pada Alat Potong Pahat Hsstipe Bohler Mo 1/2x4. Jurnal Pendidikan Teknik Mesin Undiksha, 5(1). 
Drozda, T. J. (1983). Tool and Manufacturing Engineers Handbook: Machining: Society of Manufacturing Engineers.

Faishol, M., Hastuti, S., \& Ulya, M. (2013). Perancangan ulang tata letak fasilitas produksi pabrik tahu srikandi junok Bangkalan. Agrointek, 7(2), 59-67.

Hidayat, U. (2011). Desain tata letak pabrik: plant lay out: Ikopin Press.

Jutz, H. (2006). Westermann Tables For The Metal Trade: New Age International.

Nurchajat, N. (2017, 2017). Analisis Perencanaan Anggaran Biaya Pembuatankomponen Bak Pick Up Kapasitas $840 \mathrm{Kg}$.

Phillips, E. J., \& Engineers, S. o. M. (1997). Manufacturing Plant Layout: Fundamentals and Fine Points of Optimum Facility Design: Society of Manufacturing Engineers.

Qosim, N., \& Hartono, M. (2019). Machining time and number of machine for the production planning of wheel nut releaser with the demand of 100 units/day. Int. J. of Adv. in Appl. Sci. ISSN, 2252(8814), 8814.

Roidelindho, K. (2017). Penentuan Beban Kerja Dan Jumlah Tenaga Kerja Optimal Pada Produksi Tahu. Jurnal Rekayasa Sistem Industri, 3(1), 73-80.

Sofyan, D. K., \& Syarifuddin, S. (2018). Perancangan Ulang Tata Letak Fasilitas dengan Menggunakan Metode Konvensional Berbasis 5s (Seiri, Seiton, Seiso, Seiketsu dan Shitsuke). Jurnal Teknovasi: Jurnal Teknik dan Inovasi, 2(2), 27-41.

Yang, T., \& Hung, C.-C. (2007). Multiple-attribute decision making methods for plant layout design problem. Robotics and computer-integrated manufacturing, 23(1), 126-137. 